\title{
Sensitivity to penicillin of Neisseria gonorrhoeae in Bangkok Relation to the results of treatment
}

\author{
K. PANIKABUTRA* AND S. SUVANMALIK† \\ From the Venereal Disease and Treponematosis Control Division, Bangkok, Thailand
}

The incidence of the relative resistance of different strains of gonococcus to penicillin has been increasing for some years. The present study was undertaken to assess the results of two treatment schedules using penicillin to treat uncomplicated gonorrhoea in women, and to correlate the occurrence of penicillin resistant strains in our clinic with the incidence of failure.

Increased resistance of the gonococcus to antibiotics is much more pronounced in South-East Asia and the Western Pacific Region of the World Health Organization than in most other areas (Willcox, 1970a).

In a WHO study in the Philippines, all of one series of strains were found to have reduced sensitivity to penicillin (WHO, 1963). Keys, Halverson, and Clark (1969) reported that in Hawaii between October, 1968, and April, 1969, 50 per cent. of the strains of gonococci isolated had MICs of $0.05 \mu \mathrm{g}$. and 46 per cent. had MICs of from 0.1 to $1.0 \mu \mathrm{g}$.; in the Philippines 10 per cent. had MICs of $0.05 \mu \mathrm{g}$. and 90 per cent. MICs of from 0.1 to $1.0 \mu \mathrm{g}$; in Japan 100 per cent. of the strains isolated had MICs of 0.1 to $1.0 \mathrm{\mu g}$.

In Thailand, 27 isolates of Neisseria gonorrhoeae from the Chiengmai Venereal Disease Clinic were tested for penicillin sensitivity (Forsyth, Peerakome, Roberts, and Panas-Ampol, 1971); 21 of them required $1 \mathrm{u}$. per $\mathrm{ml}$. or more to inhibit growth in vitro when a light inoculum was used. When a heavy inoculum was used, the result was at least a two-fold increase in the concentration required for inhibition.

In Bangkok, sensitivity determinations to penicillin have been carried out since April, 1968, and it has

\footnotetext{
*Physician-in-Charge of the Department for Females, Bangrak Hospital, VDT Control Division, Department of Health, Bangkok, Thailand

tChief, Central VD Laboratory, VDT Control Division, Department of Health, Bangkok, Thailand

Paper presented at the Regional Symposium on 'The Epidemiology and Control of Venereal Diseases' at Bangkok, Thailand, in December, 1971, under the auspices of the W.H.O. Regional Office for SouthEast Asia.
}

been found that both the proportion of the less sensitive strains and the extent of their insensitivity have increased (Suvanmalik, 1971). In 1968, there were 47.4 per cent. less sensitive strains (strains requiring MICs of more than $0.128 \mathrm{u} . / \mathrm{ml}$.), in 1969 48.4 per cent., and in 197059.4 per cent. The highest MIC in 1968 was $0.512 \mathrm{u} . / \mathrm{ml}$. and in 19702.048 $\mathrm{u} . / \mathrm{ml}$.

\section{Material and methods}

Female patients with uncomplicated gonorrhoea diagnosed at the Out-patient department, Bangrak Hospital, Bangkok, were selected for this study, which was conducted from November 2, 1967, to December, 1970.

The diagnosis was based on the findings of Gramnegative intracellular diplococci in the stained smears and on the results of cultures of specimens taken from the urethra and the cervix. Blood for a routine serum test for syphilis was taken in every case.

Specimens of urethral and cervical discharge were sent to the laboratory in Stuart's transport medium. Smears of exudate for microscopical examination were taken at the same time.

Cultivation was carried out on modified Carpenter medium with incubation at $35^{\circ} \mathrm{C}$. in an atmosphere containing 3 per cent. $\mathrm{CO}_{2}$. Diagnosis of infection by $N$. gonorrhoeae was made on the basis of the morphological appearance of the colonies, positive oxidase reaction, the appearance on Gram-staining, and sugar fermentation tests.

Sensitivity testing of the gonococci isolated was undertaken as part of the laboratory routine from April, 1968, onwards.

Only the patients who had positive results to cultures were included and all who admitted sexual exposure within 2 weeks of treatment were excluded from the series.

In distinguishing relapse from re-infection, the suggestion of Evans (1966) was followed. If gonococci reappeared within 14 days of treatment and if further intercourse was denied by the patient, then the infection was considered to have relapsed; the re-appearance of gonococci after 14 days, irrespective of the patient's history, was considered to be due to re-infection.

The MICs of penicillin were determined by doubling dilutions of the antibiotic on chocolate agar plates. The plates were inoculated with a multiple inoculating device 
delivering approximately $0.03 \mathrm{ml}$. of a heavy suspension of each strain. The plates were incubated for $24 \mathrm{hrs}$ in an atmosphere of 3 per cent. $\mathrm{CO}_{2}$ and the MIC was read as the lowest concentration of antibiotic which caused total inhibition of growth. The Oxford staphylococcus and resistant gonococci from previous test batches were included on all plates as controls. Sensitivity determinations were carried out before treatment. This was done as a routine procedure from April, 1968 onwards.

\section{Treatment}

The penicillin preparation used in the study was procaine penicillin fortified (PPF), which consists of three parts of procaine penicillin $G$ to one part of benzyl penicillin.

The study consisted of two series of patients:

\section{SERIES A}

(November 2, 1967, to August 31, 1968) 2.4 m.u. PPF were given on two consecutive days, a total of $4 \cdot 8 \mathrm{~m}$.u.

SERIES B

(October 1, 1968, to December 30, 1970) Single injections of $4 \mathrm{~m} . \mathrm{u}$. PPF were given.

Follow-up visits were arranged 2 to 4 days, 7 days, 14 days, 28 days, 2 months, and 3 months after treatment. Specimens for smears and cultures were taken from the urethra and cervix on each occasion. A routine serological study was performed on each patient at monthly intervals for 3 months.

\section{Results}

\section{SERIES A}

Of 155 patients, twelve failed to attend for follow-up, eight defaulted after the first injection, and 22 admitted re-exposure before the first follow-up examination. There were thus 113 cases left for assessment. The failure rate was 15.8 per cent.

\section{SERIES B}

Of 304 patients, 22 defaulted after treatment and twenty admitted re-exposure before the first follow- up examination. There were thus 262 cases left for assessment. The failure rate was 12.5 per cent.

A summary of the results obtained is given in Table I and the duration of follow-up in Table II.

TABLE II Follow-up and apparent results of treatment

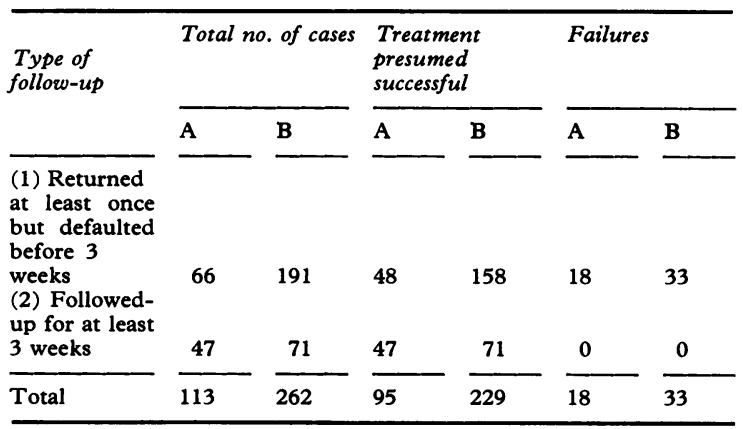

\section{Bacteriological results}

SERIES A

All of the 155 patients had positive results to cultures. The MIC of penicillin for 41 of these strains was determined, and about 60 per cent. of them showed diminished sensitivity to penicillin ( 25 out of 41 ).

\section{SERIES B}

All of the 304 patients in this series had positive results to cultures. The MIC of penicillin for 55 of these strains was determined, and about 70 per cent. of them showed diminished sensitivity to penicillin (39 out of 55).

The MIC of benzyl penicillin for the strains isolated and a comparison between the two schedules of treatment are shown in Table III (opposite).

\section{Side-effects}

Of the 155 patients in Series A, three developed anaphylactic reactions approximately 15 minutes after the intramuscular injection. There was one

TABLE I Results obtained with two treatment schedules of PPF

\begin{tabular}{|c|c|c|c|c|c|c|c|c|c|c|}
\hline \multirow{3}{*}{ Series } & \multirow{3}{*}{$\begin{array}{l}\text { Dosage } \\
(m . u .)\end{array}$} & \multirow{3}{*}{$\begin{array}{l}\text { No. of } \\
\text { doses }\end{array}$} & \multirow{3}{*}{$\begin{array}{l}\text { No. } \\
\text { treated }\end{array}$} & \multirow{3}{*}{$\begin{array}{l}\text { No. } \\
\text { defaulted } \\
\text { after } \\
\text { treatment }\end{array}$} & \multirow{3}{*}{$\begin{array}{l}\text { No. } \\
\text { treatment } \\
\text { not } \\
\text { complete }\end{array}$} & \multirow{3}{*}{$\begin{array}{l}\text { No. } \\
\text { admitted } \\
\text { re-exposure } \\
\text { before first } \\
\text { follow-up } \\
\text { examination }\end{array}$} & \multirow{3}{*}{$\begin{array}{l}\text { No. for } \\
\text { assessment } \\
\text { of results }\end{array}$} & \multicolumn{3}{|l|}{ Result } \\
\hline & & & & & & & & \multirow[t]{2}{*}{ Cured } & \multicolumn{2}{|c|}{ Not cured } \\
\hline & & & & & & & & & No. & Per cent. \\
\hline $\begin{array}{l}\text { A } \\
\text { (Nov. 2, 1967, } \\
\text { to Aug. 31, 1968) }\end{array}$ & PPF 2.4 & 2 & 155 & 12 & 8 & 22 & 113 & 95 & 18 & $15 \cdot 8$ \\
\hline $\begin{array}{l}\text { B } \\
\text { (Oct. 1, 1968, } \\
\text { to May } 10,1969)\end{array}$ & PPF 4 & 1 & 79 & 5 & - & 9 & 65 & 60 & 5 & $7 \cdot 7$ \\
\hline $\begin{array}{l}\text { (May } 11,1969 \text {, } \\
\text { to Dec. } 30,1970 \text { ) }\end{array}$ & PPF 4 & 1 & 225 & 17 & - & 11 & 197 & 169 & 28 & $14 \cdot 2$ \\
\hline $\begin{array}{l}\text { Total } \\
\text { (Oct. } 1,1968 \text {, } \\
\text { to Dec. } 30,1970 \text { ) }\end{array}$ & PPF 4 & 1 & 304 & 22 & - & 20 & 262 & 229 & 33 & $12 \cdot 5$ \\
\hline
\end{tabular}


TABLE II C Comparison between two doses of 2.4 and single dose of $4 \mathrm{m.u}$. PPF related to penicillin sensitivities

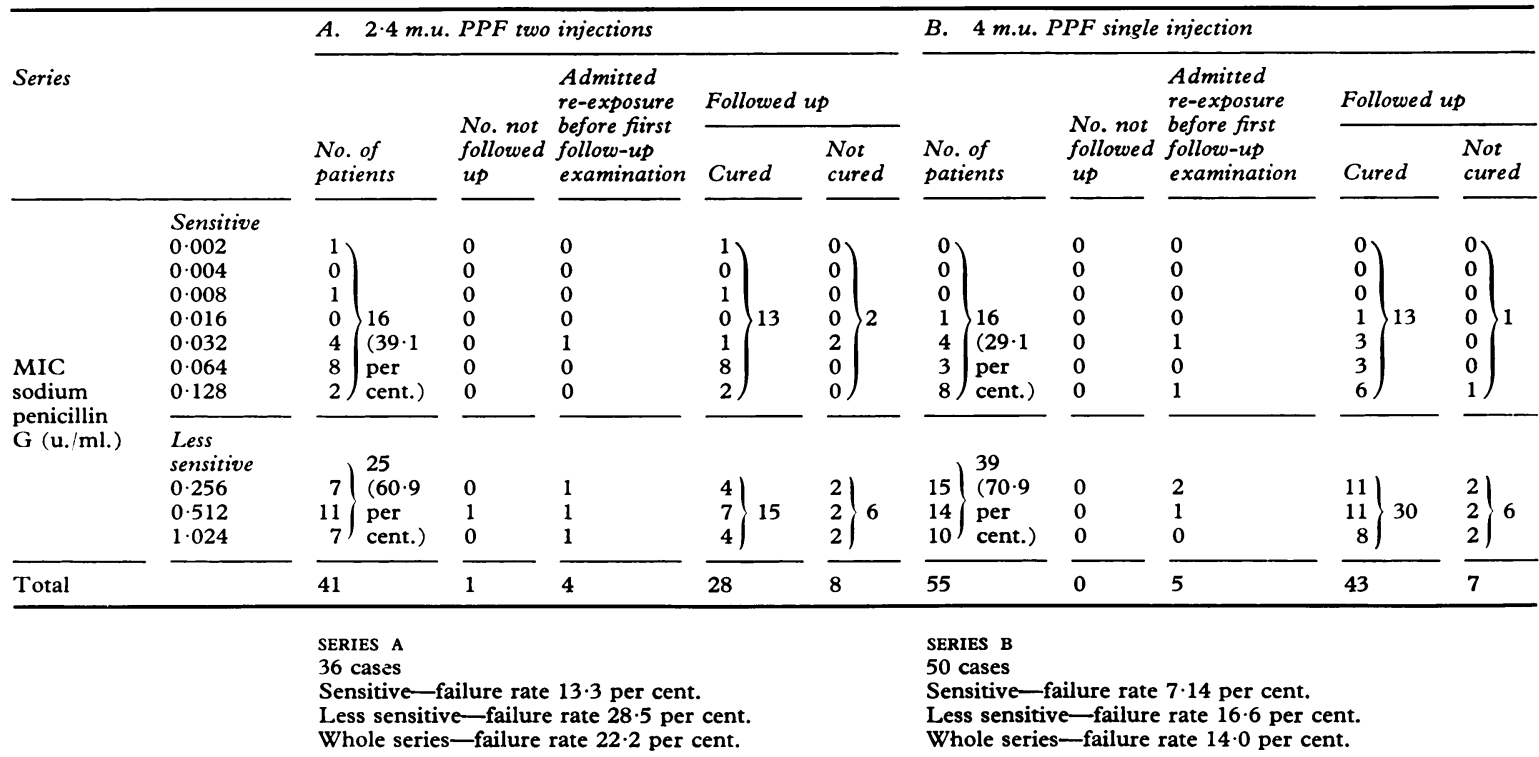

case of urticaria and one of generalized purpura.

Of the 304 patients in Series B, one developed an anaphylactic reaction within 15 minutes after injection. There were two cases of urticaria and one of generalized papular eruption.

\section{Discussion}

In the Far East and in South-East Asia, high failure rates in the treatment of gonorrhoea with penicillin, even after large doses, were reported some years ago. Single injections of $2.4 \mathrm{~m} . \mathrm{u}$. procaine penicillin $\mathrm{G}$ were followed by a failure rate in males of 29 per cent. (18 out of 63 patients) (Holmes, Johnson, and Floyd, 1967), and resist ance to $0.06 \mathrm{u} . / \mathrm{ml}$. penicillin was noted in 26 of 41 (62 per cent.) strains of $N$.gonorrhoeae from this group.

In Vietnam, gonorrhoea is a major health problem, and failure rates were reported to be high by Maurer and Schneider (1969). When men with uncomplicated gonorrhoea were given $2.4 \mathrm{~m}$.u. procaine penicillin $\mathrm{G}$ on two consecutive days, the failure rate was 25 per cent. (18 out of 71 ).

In a co-operative study carried out by the United States Naval Preventive Medicine Unit No. 6, Pearl Harbour, Hawaii, and the local health authorities, nine different single-dose regimens for the treatment of gonorrhoea were compared in a group of asymptomatic Filipino hostesses who were chronic carriers of $N$. gonorrhoeae. Single injections of combined procaine and crystalline benzyl penicillin in a 3:1 ratio were given intramuscularly in four different dosages. After two doses of 2 m.u., treatment failure occurred in four of nine cases; after 3 m.u., in nine of 26 cases; after 6 m.u., in three of 24 cases; and after 6 m.u. preceded 1 hour earlier by $1 \mathrm{~g}$. probenecid by mouth, there were no failures in eighty cases (Johnson, Kvale, Afable, Stewart, Halverson, and Holmes, 1970).

The situation is quite different in Europe. In London, it is still possible to achieve cure rates of 85.8 to 91.5 per cent. in male patients, using single injections of $1.2 \mathrm{~m} . \mathrm{u}$. aqueous procaine penicillin G (Willcox, 1970b), and the failure rate was only 5.8 per cent. in patients treated with $2.4 \mathrm{~m}$.u. procaine penicillin $\mathrm{G}$ in a single injection (Morrison, Cobbold, Bor, Spitzer, Foster, and Willcox, 1968).

In the present study, a single injection of $4 \mathrm{~m} . \mathrm{u}$. PPF (Series B) seemed to give slightly better results than two injections of 2.4 m.u. PPF (Series A). The failure rates were 12.5 and 15.8 per cent. (Table I), but the difference was not statistically significant $\left(x^{2}=0.746 ; P>0.3\right)$.

In Series $B$, the failure rate was 7.7 per cent. in the first period of the study (October 1, 1968, to May 10, 1969) (Table I), but increased to 14.2 per cent. in the second period (May 11, 1969. to December 30, 1970). These results correlated with the increase of strains of gonococci with reduced sensitivity to penicillin in Bangkok (47.4 per cent. in 1968, 48.4 per cent. in 1969, and 59.4 per cent. in 1970) (Suvanmalik, 1971).

The results of treatment correlated well with the sensitivities of $N$. gonorrhoeae to penicillin (Table III). 
In Series A, there were two failures in fifteen cases in which sensitive strains were isolated (13.3 per cent.) and six failures in 21 cases in which less sensitive strains were isolated ( 28.5 per cent.). The total failure rate among 36 cases for assessment in Series A was $22 \cdot 2$ per cent. ( 8 out of 36 ).

In Series B, one failure occurred in fourteen cases from which sensitive isolates $(7 \cdot 14$ per cent.) were obtained and six failures in 36 cases from which less sensitive strains $(16.6$ per cent.) were obtained. In all, there were seven failures among fifty cases from which isolates were available for assessment (14.0 per cent.).

\section{Summary}

(1) The results are presented of the treatment of 155 women with uncomplicated gonorrhoea in Bangkok with two injections each of 2.4 m.u. PPF given on two consecutive days between November, 1967, and August, 1968; 113 patients were followed and there were eighteen failures ( $15 \cdot 8$ per cent.).

(2) 304 women with uncomplicated gonorrhoea were treated during the period October, 1968, to December, 1970, with single injections of 4 m.u. PPF; 262 patients were followed and there were 33 failures (12.5 per cent.). These results were not significantly better than when two injections of $2.4 \mathrm{~m}$.u. PPF were used, but the single injection has the advantage of greater convenience to patients and gives no opportunity of default before the treatment is complete.

(3) Treatment failure was found to be directly related to the sensitivity of the infecting strains of gonococci.

We are grateful to Mr. Ambrose King, F.R.C.S., WHO Consultant, for his valuable criticism and advice in the preparation of this paper.

\section{References}

Evans, A. J. (1966) Brit. f. vener. Dis., 42, 251

Forsyth, P., Peerakome, S., Roberts, C. E., and Panas-Ampol, K. (1971) Chiengmai med. Bull., 10, 83

Holmes, K. K., Johnson, D. W., and Floyd, T. M. (1967) f. Amer. med. Ass., 202, 461

Johnson, D. W., Kvale, P. A., Afable, V. L., Stewart, S. D., Halverson, C. W., and Holmes, K. K. (1970) New Engl. f. Med., 283, 1

KeYs, T. F., Halverson, C. W., and Clark, E. J. (1969) f. Amer. med. Ass., 210, 857

MAURER, L. H., and SCHNEIDER, T. J. (1969) Ibid., 207, 946

Morrison, G. D., Cobbold, R. J. C., Bor, S., SPITZER, R. J., FosteR, D. N., and Willcox, R. R. (1968) Brit. F. vener. Dis., 44, 319

SUVANMALIK, S. (1971) Unpublished report.

WHO (1963) Expert Committee on Gonococcal Infections. First Report. Tech. Rep. Ser. No. 262, pp. 3435. WHO, Geneva

Willcox, R. R. (1970a) Brit. f. vener. Dis., 46, 217

- (1970b) Ibid., 46, 141

Sensibilité du Neisseria gonorrhoeae à la pénicilline à Bangkok. Rapport avec les résultats du traitement

\section{SOMMAIRE}

(1) On présente les résultats du traitement de 55 femmes atteintes, à Bangkok, de gonococcie non compliquée par deux injections, chaque fois, de 2,4 m.u. de 'PPF' données en deux jours consécutifs de Novembre 1967 à Aout $1968 ; 113$ malades ont été suivies et il y eut 18 échecs $(15,8$ pour cent).

(2) 304 femmes atteintes de gonococcie non compliquée ont été traitées entre Octobre 1968 et Décembre 1970 par une injection unique de 4 m.u. de PPF; 262 malades furent suivies et il y eut 33 échecs (12,5 pour cent). Ces résultats ne sont pas significativement meilleurs que lorsque l'on utilisait deux injections de 2,4 m.u. de PPF, mais l'injection unique a l'avantage de convenir mieux aux malades et ne donne pas l'occasion à ceux-ci de se dérober avant la fin du traitement.

(3) Les échecs thérapeutiques se sont trouvés directement en relation avec la sensibilité des souches des gonocoques infectants. 